\section{THE OXFORD MEETING OF THE BRITISH ASSOCIATION.}

THERE are already signs that the meeting of the British Association, to be held this year at Oxford, will be a success. It is unfortunate, perhaps, that the city of Oxford is this year destitute of municipal buildings, the old buildings having been pulled down, while the new have scarcely their walls raised to the level of the first floor. But this deficiency is amply compensated by the numerous University and College buildings which have been placed at the disposal of the Local Executive Committee. The reception room will be in the entrance hall of the new Examination Schools in High Street, and the rooms for the meetings of Council, of the General Committee, and of Sections $\mathrm{E}$ and $\mathrm{F}$ will be held in the same building, the large south and east writing schools lending themselves particularly well for the departments of Geography and Economics and Statistics. The meeting rooms of the remaining sections will be distributed among the University Museum and among Colleges which are on the direct road between the Schools and the Museum. Section A (Mathematical and Physical Science) will meet in the Lecture Theatre of the Clarendon Laboratory, and the allied Section G (Mechanical Science) will meet in close contiguity in Keble College Hall. Section B (Chemistry) will meet in the Chemical Theatre, and for larger meetings will have the use of the large Lecture Theatre in the Museum. Section C (Geology) will meet in Hertford College Hall; Section $\mathrm{D}$ (Biology) in the Anatomical Theatre. Section $\mathrm{H}$ (Anthropology) will be accommodated in Prof. Arthur Thomson's new Hall of Anatomy, and will have the advantage of being in close proximity to the Pitt-Rivers Museum. The new Section I (Physiology) will perhaps be better off than any, as the whole of the new Physiological Laboratories will be at its disposal.

The proceedings will begin on the evening of Vednesday, August 8, when Prof. Burdon Sanderson will resign the presidency, and the new President, the Most Hon. the Marquis of Salisbury, K.G., Chancellor of the University, will deliver the opening address. On the Thursday evening there will be a conversazione in the University Museum. On the Friday evening Mr. WV. H. White, C.B., will give an evening lecture in the Sheldonian Theatre, on "Steam Navigation at High Speeds." The Saturday evening lecture to working men will be given by Prof. Sollas. On Monday evening Prof. J. Shields Nicholson will lecture in the Sheldonian Theatre, on "Historical Progress and Ideal Socialism," and the Tuesday evening will be occupied by a conversazione, which will probably be given in the new Examination Schools. Invitations to foreign investigators have been issued by the Local Executive Committee, and nearly eighty have already signified their intention to attend the meeting, amongst them being Prof. Quincke, Prof. Oskar Schlömilch, Prof. Moritz Cantor, Prof. Kohlrausch, Prof. Strasburger, Prince Roland Bonaparte, Prof. Anoutchine, M. Cartailhac, Dr. Mojsisovics von Mojsvar, Prof. Maxime Kovalevskij, Prof. Victor Carus, Prof. E. van Beneden, Prof. Dames, Prof. F. von Sandberger, Prof. F. Schmidt, Prof. Taussig, Prof. Ostwald, Prof. Beilstein, and many other notabilities in every branch of science. Nearly every prominent English man of science has already expressed his intention of being present, and there can be little doubt that the Oxford meeting of 1894 will equal in interest the last Oxford meeting of 1860 , which was made celebrated by Prof. Huxley's spirited defence of the then novel doctrine of Darwinism.

The Local Secretaries for the Oxford meeting are Messrs. G. C. Bourne, G. Claridge Druce, and D. H. Nagel, and any communications respecting the meeting should be addressed to them at the University Museum, Oxford.

\section{EXHIBITIONS OF PHYSICAL APPARATUS.}

$\mathrm{I}$ the days when $a$ priori reasoning reigned supreme,

when all observations which were not found in the works of early writers were regarded with suspicion, and all facts had to stand or fall according to their relation to metaphysics, there was no demand for scientific instruments and apparatus. A cause or a principle was then stated like a proposition in mathematics, and the effects which follow upon it were deduced; nowadays the scientific method is to observe the effects, and afterwards formulate a law which embraces them. To carry out this method of experiment and induction, apparatus is needed, and hence the state of physical science at any epoch can be estimated by the character of the instruments at the disposal of investigators. Judged by this criterion, physics and astronomy must have attained a marvellous degree of accuracy. The intricate nature of some physical instruments, and the complicated accessories with which all large astronomical telescopes are now equipped, not only testify to the skill of the instrumentmaker, but also represent engines of research whereby new fields are explored. These instruments thus afford tangible evidence of advance, and it is for this reason that their exhibition is to be commended. Such an exhibition of physical instruments was lately held at Paris by the Société Française de Physique, and it is well worthy of imitation on this side of the Channel.

The apparatus of physics falls naturally into two classes - that used for lectures, and that belonging more especially to the laboratory. The apparatus employed in teaching elementary science cannot be too simple and the experiments performed with it should be so clearly shown that the facts they exemplify become evident to the most obtuse student. In many cases this tenet of experimental philosophy is disregarded, the lecturer aiming at producing brilliant effects-stage fireworks, as they have been appropriately cailed-rather than the illustration of a physical law. In fact, there is a tendency to push lecture-room experimentation too far, to use the lectureassistant's skill as a make-up for lack of eloquence. The popular mind looks in awe upon the abundance of instruments arranged for this end, but it may be doubted whether, under such circumstances, the points of the discourse are not often obscured.

As to laboratory experiments for students, each should constitute a little investigation in itself. An experiment consists in changing the conditions and arrangements of natural bodies in order to examine their behaviour. The student should, therefore, be given the apparatus required to demonstrate a principle, and should be told what to do with it, but the inference to be drawn from his observations should be left entirely to him. If it is necessary to tell him what the experiment proves, then the object of his work has not been attained. By following this method, and properly grading the experiments, the student not only derives considerable educational benefit in learning to think for himself, but the instinct for research is also stimulated. In many colleges and institutions where the aim is to rush the student through as much experimental work as possible in a short time, the apparatus is all arranged for the student, who merely presses a knob and sees a galvanometer needle wriggle, or something of the kind. There can be no independent thinking in such cases, and, except for examinational purposes, the experiments might just as well be left undone. Most physicists agree with these opinions, and, by arranging an exhibition of apparatus, the Physical Society would help to impress their importance upon teachers. Sets of apparatus suitable for lectures and for practical work in various branches of physics might be arranged for exhibition by a committee, and these, with the instruments of precision, would make an extremely interesting, as well as useful, collection.

NO. I 285 , VOL. 50 
The exhibition of physical apparatus at Paris comprised numerous ingenious instruments, but there was no attempt at arranging educational sets. Lord Kelvin's voltmeters and ammeters were shown, and various instruments for measuring electric energy and resistance. A binocular photometer attracted some attention, and also a new kind of ophthalometer and a monochromato. scope. M. V. Chabaud showed a form of electrometer devised by M. Lippmann, several pieces of apparatus made from dielectrine, tolueine thermometers for the measurement of low temperatures, Villard manometers, Varenne's apparatus for fractional distillation, and Bichat's hygrometers. M. J. Carpentier's exhıbit included mica condensors, and an instrument invented by General Sebert for determining the rapidity of photographic plates. MI. J. Richard showed a meteorograph constructed for the observatory on Mont Blanc, an electric anemometer, Favé sounding-line, and numerous recording voltmeters and ammeters. His exhibit also comprised, among other things, several of Bonetti's electrical machines, Berlemont's mercury pump, and various sterilisers. The photographs of interference fringes obtained by M. Meslin call for special mention, and also a penduam devised by Captain Colson for measuring short exposures in photography, and a theodolite adapted to photographic work by MI. Echassoux. The French Photographic Society exhibited sets of photographic apparatus, and M. G. Raymond some fine cloud photographs. The apparatus used by M. Marey for photographing objects in motion, naturally found a place in the exhibition. Photographs in colours, obtained by the Lippmann method, were seen by projection, and were greatly admired. Many other results of scientific rejearch were shown, together with the instruments by means of which they were obtained, but no useful purpose would be served by enumerating them. It is proposed to hold a similar exhibition next year, and if instrument-makers co-operate with investigators as they did in the one just closed, there can be no doubt as to its value to workers in all branches of physics.

There should be little difficulty in arranging an annual exhibition of a similar kind in London. Scientific instrument-makers would compete with one another in showing work of a high quality, and if the exhibits were organised by a competent committee, the venture would be successful from every point of view.

R. A. G.

\section{AUGUST KUNDT.}

PHYSICAL science, which within the lapse of six years has witnessed the death of Kirchhoif, Clausius, and Hertz, has suffered another severe loss ; on May $2 \mathrm{r}$, August Kundt, who was but fifty-four years of age, suddenly died at his country place near Lübeck.

Kundt was born at Schwerin, on November 18,1839 , and began his studies at Leipzig in 1860 , under Hankel, Neumann, Bruhns, and others. Thence he went to Berlin, where Encke, Förster, Dove, and Kummer were his principal teachers. He began by giving special attention to astronomy, and indeed intended to devote himself to that branch of science. While yet undecided, however, he entered the private physical laboratory that Gustav Magnus had fitted out in the Prussian capital, and in which students with a decided taste for experimental investigation were allowed to work. From the beginning he displayed extraordinary experimental ability, combined with rare energy in the pursuit of the work he had once taken in hand, qualities which were characteristic of him during his whole scientific career. He also attended the physical "colloquia" which Magnus had introduced, and under the intluence of the latter was definitely enrolled in the lists of experimental physicists.

He graduated at Berlin in April 1854 , with an investiga. NO. I 285 , voL. 50] tion on the depolarisation of light. The first and last of the theses appended to his dissertation (dedicated to Magnus) are characteristic of the state of his mind at that time. They run as follows:-

(1) Vires anima non minus metiri possumus, quam vires physicas. . .

(4) Theoriam a $\dot{\mathrm{C}}$. Fresnel de torsione planitiei polarisationis promulgatam si adoptamus, omnia ea corpora quæe planitiem polarisationis torquent, sub aptis conditionibus birefractionem demonstratura esse, negare non possumus.

He never himself followed up the psychological lines of research hinted at in the first thesis; the last proposition is known to be entirely borne out by modern research on circular double refraction.

In 1867 he became "Privatdocent" in the University of Berlin, but was appointed to a professorship in the Swiss federal polytechnic school at Zurich, in the follow: ing year. There he remained but two years, removing to VWürzburg in 1870 , where his stay was of no longer duration, the then newly organised University of Strasburg having called him to represent his science on a brilliant staff of young and enterprising men, who within a few years brought their "alma mater" to a high level of excellence. In this work of organisation Kundt was one of the most actively engaged, holding the office of rector in the year 1877 , when but 38 years of age. Quite apart from his purely scientific reputation, this alone is sufficient to mark his name with golden letters in the annals of Strasburg University, for which he also erected an imperishable monument, the Physical Institute, well known throughout the scientific world as one of the best laboratories existing.

In I 888 , when Prof. von Helmholtz became president of the "Reichsanstalt," Kundt succeeded him as professor of experimental physics, and director of the Berlin Physical Institute. A prolonged period of scientific activity from a man of but fifty years of age with a worldwide reputation might still have been expected ; but these hopes have proved vain. A few years ago the symptoms of a disease began to appear, which could not be subdued. Kundt fought for life to the last; and notwithstanding the slow but unceasing strides his ailment made, which would have entirely prostrated most other men, he continued his lectures and other pressing duties during the whole of last winter, thus setting an example of sacrifice to the cause of science even in the face of death. When, at the urgent instance of his medical advisers and friends, he stopped work and left Berlin, it proved of no avail; in fact, he may be said to have died as he had lived, in the midst of scientific work.

As an investigator Kundt was many-sided; his discoveries are so generally known, that it is hardly necessary to describe them in detail. He first turned his attention to acoustics; his start in scientific life being the invention of the well-known "Kundt's sound tubes," or "Kundt's dust figures," which he himself and others turned to account in many different ways. The application of that purely acoustic method led to the determination of the ratio of specific heats of mercury vapour. In collaboration with Varburg ( $\left.188_{4}\right)$, Kundt found this to be $5 / 3$, as predicted by the kinetic theory for a monatomic gas. He also conducted researches on thermal conductivity and inter-diffusion of gases or vapours and on the influence of pressure on the surface tension of liquids; and developed his well-known red and yellow dust-spray method for investigating the pyro-electric and piezoelectric properties of crystals.

But in glancing over his life-work as it now lies before us, it appears as if the falm ought to be assigned to his optical and magneto-optic discoveries. He began with a brilliant series of papers on anomalous dispersion, which placed this important subject on a sound footing. He described the doubly refractive properties of vibrating solids, 